\title{
Comparative photosynthetic responses of big bluestem to clipping versus grazing
}

\section{L.L. WALLACE}

Abstruct

The gas exchange responses of big bluestem (Andropogon gerardit) were followed after defoliation by either cattle grazing or clipping and compared with the response of nondefoliated (control) plants. Grazed plants had significantly higher rates of photosyntheais than either clipped or control plants. The photoayntheis/transpiration ratio as well as stomatal sensitivity to humidity indicate that leaves of grazed plants may have developed in a higher light and lower moisture environment than that of their clipped counterparts. Although the experimental dealgn could not preclude any indirect effects of animal aetivity (aliva, waste products, or trampling) on the grazed plants, the microenvironmental differences caused by graxing may be crucial in determining the responses of grases to clipping versus graing.

Key Words: Andropogon gerardit, Oklahoma, stomatal sensitivity, photosynthesis/transpiration ratio

A great deal of interest has been expressed in graminoid response to defoliation. Studies have focused on herbage production, plant morphology, and plant growth in response to defoliation, as well as responses to the method of defoliation, clipping versus grazing (Robinson et al. 1937, Vickery 1972, Reardon et al. 1974, Howe et al. 1982, King et al. 1984). The consensus appears to be that clipping or mowing a sward at a given height does not adequately mimic grazing. The primary reasons for this difference are: (a) grazing does not remove uniform amounts of forage from all tillers, hence removal of herbage from all tillers is unrealistically severe (Stroud et al. 1985), and (b) grazing animals have substantial indirect effects such as soil compaction and recycling of nutrients via dung and urine (Bauer et al. 1987; Wallace 1987a, b) that are not mimicked by clipping. Unfortunately, there have been few explicit tests of these mechanisms.

In this study, I attempted to ascertain some of the mechanisms which account for the differences that have been shown between clipping and grazing. By examining the photosynthetic responses of grazed, clipped, and nondefoliated (control) plants, I wished to determine which factors were not most closely correlated with plant response to these forms of defoliation. I expected that changes should be found in plant physiology that may precede changes that have been noted in plant morphology and productivity. Thus, the data presented here represent a preliminary assessment of the differences in the responses of big bluestem (Andropogon gerardii) to either clipping or grazing.

\section{Methods}

Three $40 \times 40-\mathrm{m}$ plots were established adjacent to one another in tallgrass prairie at the USDA Livestock and Forage Experiment Station at El Reno, Okla. The plots were located on a upland prairie site on fine, mixed thermic Udertic paleustolls (USDA

\footnotetext{
Author is an associate professor, Department of Botany and Microbiology, University of Oklahoma, Norman 73019 .

Research was funded in part by National Science Foundation Grant BSR 8307117 The author wishes to acknowledge the assistance of the personnel at the USDA Forage and Livestock Experiment Station at El Reno, Okla. Drs. M.M. Caldwell, E.L. Rice, S.L. Collins, and T. Svejcar reviewed an earlier draft of the manuscript. Manuscript accepted 27 April 1989.
}

1976). Dominant plants in 3 plots included Andropogon gerardii, Schizachyrium scoparium, Sporobolus asper, Sorghastrum nutans, Panicum virgatum, Vernonia spp. and Ambrosia psilostachya. Nomenclature follows Correll and Johnston (1979).

Each of the 3 plots was delineated using 3 strands of electrical fencing. Within each plot were two $2.5 \times 2.5-\mathrm{m}$ exclosures, also constructed of electrical fencing. No microclimatic differences were found in the plots due to the presence of the fence. Half of each exclosure was left undefoliated while the other half was used for the clipping treatment.

Plants were grazed for 3 days with 20 steers during the third week in June, 1987, and the third week in July (the equivalent of 14 animals / ha as opposed to the recommended stocking rate of 0.5 animals/ha; S. Coleman, pers. comm.). This extremely high stocking rate was used to ensure that all plants within each plot were equally grazed. This was found to be the case since sward height was approximately $40 \mathrm{~cm}$ prior to grazing in June and $5-10 \mathrm{~cm}$ after grazing. Sward height was approximately $15 \mathrm{~cm}$ prior to grazing in July and was approximately $5 \mathrm{~cm}$ afterwards. Each plot was grazed to the extent that there was no litter and bare ground was exposed between plants. Sward height in the control plots averaged $52 \mathrm{~cm}$ prior to the July defoliation sequence. Litter accumulated to a depth of approximately $5 \mathrm{~cm}$ in both the clipped and control plots.

Clipping was done on the day that the animals were removed from a given plot and was done to the same height as the grazed plants. A nylon string "weed-eater" was used for clipping. Leaf blades remaining after each clipping and grazing were approximately $2 \mathrm{~cm}$ long. Therefore, most of the photosynthetic area of these plants was sheath tissue immediately after defoliation. Following animal removal from 1 plot, animals were rotated onto the adjacent plot for 3 days of grazing. Following that, animals were rotated onto the final plots for 3 days. This yielded a time series of measurements with sequential plots each having 3 days less time for recovery from grazing or clipping. Gas exchange measurements were taken 1 week and 2 weeks (in the first defoliation sequence only) following cessation of grazing in the first plot.

Gas exchange measurements were taken on the youngest, fully expanded leaves of big bluestem in grazed, clipped, and nondefoliated (control) treatments using a LiCor 6000 (LiCor, Lincoln, Neb.) portable, closed gas exchange system. Eight plants were measured per treatment per plot, yielding a total of 8 leaves per treatment in a plot. Four leaves of each treatment were measured inside each exclosure, yielding 8 leaves per treatment for the 2 exclosures. Leaves were held horizontally by the chamber during the 30-second measurement period. Stomatal conductance, transpiration rates and net photosynthesis were determined along with measurements of relative humidity, quatum flux, leaf temperature, air temperature, and vapor pressure deficits (VPD). Chamber air was well-stirred so that the boundary layer remained constant and negligible during measurements. All gas exchange measurements were taken between 1100 and 1330 CST on each measurement day. All samples were measured within this time frame to minimize variation due to diurnal environmental change. 
Prior to gas exchange measurements, 4 samples per treatment per plot were taken for gravimetric determination of soil moisture (10-15 cm depth). In addition, in July, samples were taken for determination of soil bulk density.

Tests for significant treatment and data effects were run using ANOVA's. Statistical significance was assumed at $p \leq .05$.

\section{Results}

\section{Abiotic Parameters}

There were no significant differences in quantum flux, leaf temperature, relative humidity, or soil bulk density between treatments at any date (Table 1). Minor differences in VPD were found

Table 1. Average values of incident light ( $\mu$ mole-2 $\left.\mathrm{s}^{1}\right)$, leaf temperature $(\circ$ C), relative humidity $(\%)$ and vapor preacure deficit (mbars) at each sampling date. Values in a row followed by the same letter are not a'pnificantly difiorent at $p \leq .05$, Duncans Multiple Range Teat.

\begin{tabular}{llccc}
\hline \hline Parameter & Date & Control & Clipped & Grazed \\
\hline Light & $6 / 24$ & $992^{\mathrm{a}}$ & $997^{\mathrm{a}}$ & $1100^{\mathrm{a}}$ \\
& $7 / 1$ & $1623^{\mathrm{a}}$ & $1597^{\mathrm{a}}$ & $1684^{\mathrm{a}}$ \\
& $8 / 4$ & $1591^{\mathrm{a}}$ & $1560^{\mathrm{a}}$ & $1452^{\mathrm{a}}$ \\
Temperature & $6 / 24$ & $32.8^{\mathrm{a}}$ & $33.2^{\mathrm{a}}$ & $32.6^{\mathrm{a}}$ \\
& $7 / 1$ & $37.1^{\mathrm{a}}$ & $35.9^{\mathrm{a}}$ & $35.6^{\mathrm{a}}$ \\
& $8 / 4$ & $37.7^{\mathrm{a}}$ & $38.2^{\mathrm{a}}$ & $37.2^{\mathrm{a}}$ \\
Humidity & $6 / 24$ & $30.1^{\mathrm{a}}$ & $28.4^{\mathrm{a}}$ & $29.1^{\mathrm{a}}$ \\
& $7 / 1$ & $28.7^{\mathrm{a}}$ & $28.8^{\mathrm{a}}$ & $-31.1^{\mathrm{a}}$ \\
& $8 / 4$ & $24.5^{\mathrm{a}}$ & $23.4^{\mathrm{a}}$ & $24.2^{\mathrm{a}}$ \\
VPD & $6 / 24$ & $34.2^{\mathrm{a}}$ & $35.8^{\mathrm{a}}$ & $34.7^{\mathrm{a}}$ \\
& $7 / 1$ & $45.8^{\mathrm{a}}$ & $43.6^{\mathrm{ab}}$ & $40.6^{\mathrm{b}}$ \\
& $8 / 4$ & $49.0^{\mathrm{a}}$ & $52.6^{\mathrm{a}}$ & $49.3^{\mathrm{a}}$ \\
\hline
\end{tabular}

in July. Significant differences $(p<.05)$ were found in soil moisture in the July and August samples with clipped plots having significantly more moisture than the other treatments (July clipped = $10.48 \%^{\mathrm{a}}$, control $=9.68 \%^{\mathrm{b}}$, grazed $=9.03 \%$; August clipped $=$ $0.21 \%^{\mathrm{a}}$, control $=0.17^{\mathrm{b}}$, grazed $\left.=0.14 \%^{\mathrm{b}}\right)$. Values for each month followed by the same letter are not significantly different. It is unlikely that the differences noted in August were biologically important because they were so dry.

\section{Gas Exchange}

Plants in both defoliation treatments had rates of photosynthesis which were initially depressed relative to the control leaves, but rates increased by day 5 (Fig. 1). After day 3 of the first defoliation sequence, photosynthesis of leaves on the grazed plants was always higher than that of clipped leaves. This difference was significant

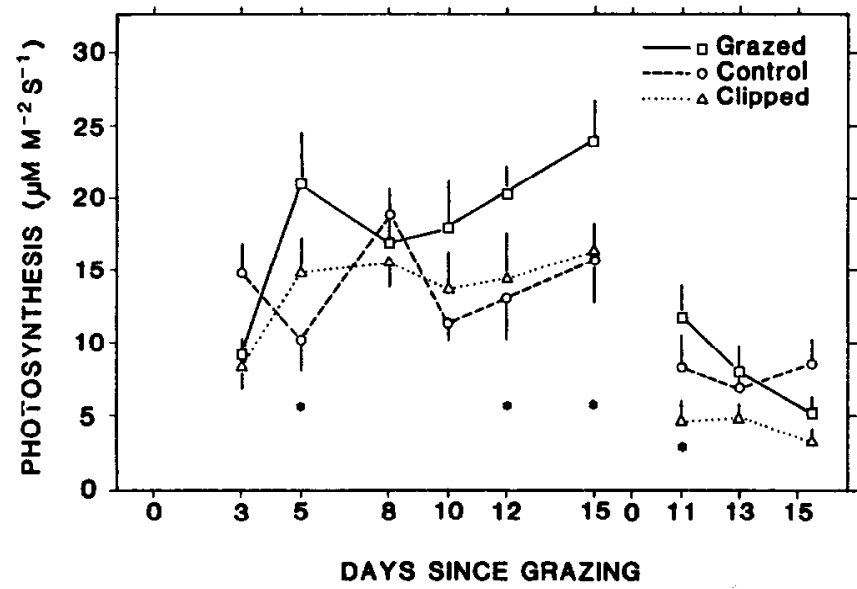

Fig. 1. Time course of photonyntheds after defoliation for both defolintion sequences. Significant $(p \leq .05)$ differences between clipped and grazed plants are denoted by an asteriak. Bars represent one standard error of the means plotted for each date and treatment $(n=8)$. on days 12 and 15 . However, following day 5 , the photosynthetic rate of the clipped leaves was never significantly different from the controls. The second defoliation sequence occurred during a seasonal drought. Although rates were much lower than in the first sequence, clipped leaves had the lowest rates of all of the treatments, with this difference being significant on days 11 and 13 .

There were fewer differences between defoliation treatments in stomatal conductances or transpiration rates (Fig. 2). Grazed

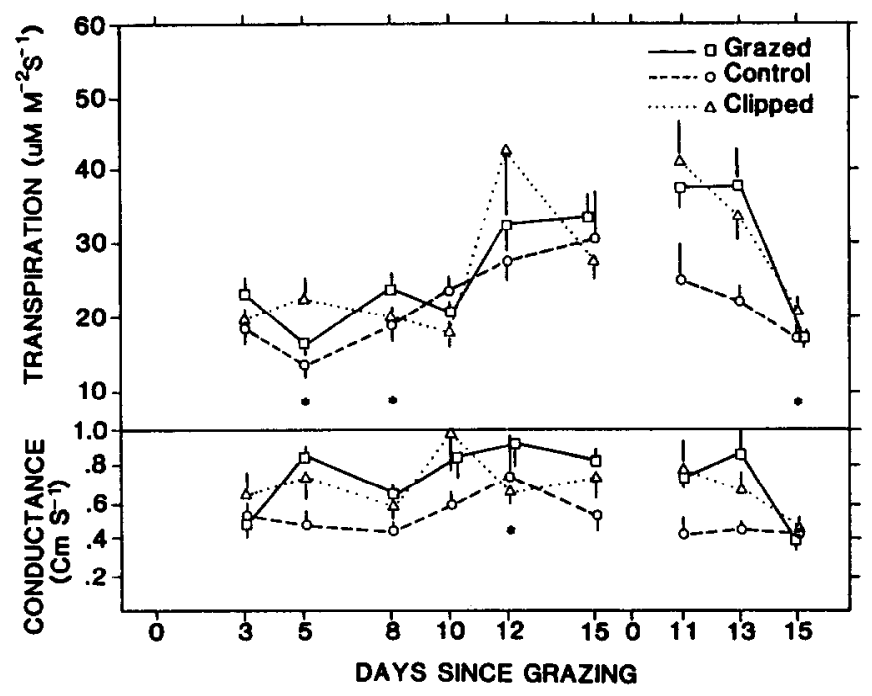

Fic. 2. Time course of stomatal conductance and transpiration after defoliation. Treatment codes and lezends are as in Flgure 1.

leaves had significantly greater stomatal conductance than clipped leaves only once. However, both defoliation treatments tended to have greater stomatal conductance values than the control treatment. Transpiration rates were also greater in the defoliated leaves. However, there was no consistent pattern of difference between the clipped and grazed treatments.

Stomatal sensitivity to humidity (transpiration/VPD) was significantly affected by treatments, with control leaves being significantly less sensitive than either defoliation treatment (grazed mean $=0.65$, clipped $=0.64$, control $=0.48$ ). There was also a significant date effect, with leaves in July being more sensitive than leaves at other measurement dates. There were no significant interactions between date and treatment.

Multiple regression analysis was conducted on photosynthetic rates for all 3 treatments at all dates to ascertain what factors appeared to be the most highly correlated with photosynthetic rates (Table 2). Grazed leaves showed little correlation with transpiration whereas both clipped and control leaves had negative correlations with transpiration in July. All treatments showed positive, strong correlations with stomatal conductance. Correlations with incident light were always positive but were of less importance to the model than were correlations with stomatal characteristics and indications of water availability (soil moisture and VPD). Thus differences between treatments appear to be how the clipped and control leaves respond to moisture availability.

\section{Discussion}

Increased rates of photosynthesis following grazing and clipping were reported in several studies (Vickery 1972, Detling et al. 1979, Painter and Detling 1981, Detling and Painter 1983, Wallace et al. 1984). Some of these studies correlated increased photosynthesis with increased stomatal conductance (Gifford and Marshall 1973, Painter and Detling 1981, Detling and Painter 1983, Wallace et al. 1984). In this study, photosynthesis was also found to be positively correlated with stomatal conductance similar to these cited results. 
Table 2. Factors which significantly $(p<.05)$ correlated with photonyntheals in each treatment. Correlation coeficients are given for each factor as well as the significance terms for the whole model determined by stepwise multiple regresion.

\begin{tabular}{|c|c|c|c|c|c|c|c|c|c|}
\hline Date & Control & $\mathbf{R}^{2}$ & $\mathbf{p}$ & Clipped & $\mathbf{R}^{2}$ & $\mathbf{p}$ & Grazed & $\mathbf{R}^{2}$ & $\mathbf{p}$ \\
\hline $6 / 24$ & $\begin{array}{r}-.34 \mathrm{VPD} \\
.39 \mathrm{Tran} \\
.011 \mathrm{QU}\end{array}$ & .901 & .0001 & $\begin{array}{c}9.7 \mathrm{CM} \\
-1.8 \mathrm{Smst} \\
.006 \mathrm{QU}\end{array}$ & .562 & .0011 & $\begin{array}{l}25.4 \mathrm{CM} \\
.0101 \mathrm{QU}\end{array}$ & .808 & .0001 \\
\hline $7 / 1$ & $\begin{array}{l}42.4 \mathrm{CM} \\
-.9 \mathrm{Tran}\end{array}$ & .878 & .0001 & $\begin{array}{l}\text { 33.6 CM } \\
-1 \text { Tran } \\
006 \text { OU }\end{array}$ & 613 & 0004 & $\begin{array}{c}-1.4 \mathrm{VPD} \\
8.0 \mathrm{CM} \\
2.4 \mathrm{LT}\end{array}$ & & \\
\hline $8 / 4$ & $\begin{array}{l}-18.2 \mathrm{CM} \\
-427 \text { Smst }\end{array}$ & .740 & .0001 & $5.606 \mathrm{CM}$ & $\begin{array}{l}.613 \\
.367\end{array}$ & $\begin{array}{l}.0004 \\
.0017\end{array}$ & $\begin{array}{l}2.4 \mathrm{LT} \\
\mathrm{NS}\end{array}$ & .671 & .0001 \\
\hline
\end{tabular}

*CM = stomatal conductance $\left(\mathrm{cm} \mathrm{s}^{-1}\right)$, Tran $=$ transpiration $\left(m\right.$ mole $\left.\mathrm{H}_{2} \mathrm{O} \mathrm{m}^{-2} \mathrm{~s}^{-1}\right)$, Smst $=$ soil moisture $(\%), \mathrm{QU}=$ quantum flux $\left(\mathrm{mmole} \mathrm{m}^{-2} \mathrm{~s}{ }^{-1}\right), \mathrm{VPD}=$ vapor pressure deficit (mbars), LT = leaf temperature $\left({ }^{\circ} \mathrm{C}\right.$ ), NS = no significant model found.

However, the increase in photosynthesis over time in the first defoliation sequence was not mirrored in the response of stomatal conductance (Figs. 1,2). The difference in photosynthesis can not be ascribed solely to differences in conductance. This may be partially explained by the low soil moisture content in the grazed plots since litter may have acted as a mulch in the clipped and control plots. This is contrary to expected results (Wraith et al. 1987).

In the few studies that have explicitly tested the differences between clipped and grazed plants, the greater production or growth of the grazed plants was attributed to differences in leaf display, leaf population age structure, and the nonuniform nature of herbivory (White 1973, King et al. 1984, Parsons et al. 1984). In grazed plants, increases in photosynthesis following grazing have also been attributed to increased incidence of light on previously subtending leaves (Mcnaughton et al. 1981, Caldwell et al. 1983). Caldwell et al. (1983) found that leaves near the interior of bunchgrass canopies exhibited extreme saturation-type light response curves with very low light saturation points. They attributed this to the fact that these leaves developed in a very low light environment: In this study, leaves of the grazed plants were the least shaded since there was extreme canopy reduction and bare ground exposed between plants.

Another method of evaluating the physiological status of a leaf is to examine the ratio of photosynthesis to transpiration $(P / T)$ (Caldwell et al. 1983). They found that leaves that had developed in the sun had higher $P / T$ ratios than did leaves that had developed in the shade. However, $I$ found no such pattern of change in $P / T$ ratios over time following either clipping or grazing (Fig. 3). Unlike

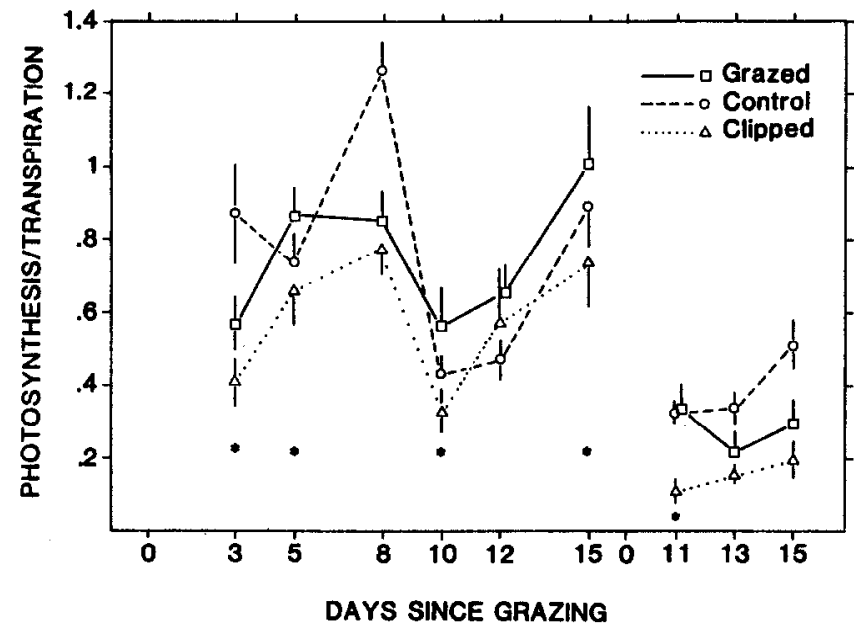

Fig. 3. Time course of the ratio of photosynthesis to transpiration after defoliation. Treatment codes are as in Figure 1.
Nowak and Caldwell (1984), I did find that leaves of grazed plants had the highest $P / T$ ratios 4 of the 6 measurement days of the first defoliation sequence and were significant greater than leaves of clipped plants 5 out of 6 measurement days. More data will be necessary for a definitive discussion of plant response to canopy structure changes, but these differences indicate that the microclimatic changes in light intensity that accompany ungulate herbivory may be important in plant response.

Additional studies have quantified the defoliation probability for tillers exposed to grazing ungulates (Briske and Stuth 1982). The proportion of tillers defoliated after 33 days of moderate grazing was not $100 \%$, as it would be in the clipped or mowed systems. Although most tillers were defoliated once or twice during this period, plants were not completely defoliated nor were all tillers on a plant grazed at any one time. This would allow for the canopy to be much more open in patches with a greater penetration of light to the base of the plant in those areas. Light penetration models (Sheehy and Cook 1977) have shown increased light intensities in grass canopies with canopy gaps that would occur in differentially grazed systems. Several authors have cited increased light as the reason for high productivity and/or tillering of grazed swards (McNaughton et al. 1981, King et al. 1984, Parsons et al. 1984). In mowed swards, light penetration was actually found to be decreased in one study (Ludlow and Charles-Edwards 1980). In this study, the extremely intense grazing opened the canopy to the point that bare ground was exposed between plants. It would be reasonable to expect, then, that leaves in the grazed plots, would have developed in high light conditions.

In this study, greater rates of photosynthesis may be due to changes in the abiotic environment of the individual leaf. This study was not designed to separate any other effects of grazing animals, i.e., saliva or trampling. Mechanisms do exist for more closely imitating the grazing process via clipping (Stroud et al. 1985), and these should be utilized to test for the effects of animal saliva on plant growth and physiological responses to herbivory.

\section{Literature Cited}

Bauer, A., C.V. Cole, and A.L. Black. 1987. Soil property comparisons in virgin grasslands between grazed and nongrazed management systems. Soil Sci. Soc. Amer. J. 51:176-182.

Briske, D.D. and J.W. Stuth. 1982. Tiller defoliation in a moderate and heavy grazing regime. J. Range Manage. 35:511-514.

Caldwell, M.M., T.J. Dean, R.S. Nowak, R.S. Dzurec, and J.H. Richards 1983. Bunchgrass architecture, light interception, and water-use efficiency: assessment by fiber-optic quadrats and gas exchange. Oecologia (Berlin) 59:178-184.

Correll, D.S., and M.C. Johnston. 1979. Manual of the vascular plants of Texas. University of Texas at Dallas, Dallas.

Detling, J.K., M.I. Dyer. and D.T. Winn. 1979. Net photosynthesis, root respiration and regrowth of Bouteloua gracilis following simulated grazing. Oecologia (Berlin) 41:127-134.

Detling, J.K. and E.L. Painter. 1983. Defoliation responses of western wheatgrass populations with diverse histories of prairie dog grazing. Oecologia (Berlin) 57:65-71. 
Gifiord, R.M. and C. Marshall. 1973. The photosynthesis and assimilate distribution in Lolium multiflorum Lam. following differential tiller defoliation. Aust. J. Biol. Sci. 26:517-526.

Howe, J.G., W.E. Grant, L.J. Flose. 1982. Effects of grazing by Sigmodon hispidus on the regrowth of annual rye-grass (Lolium perenne). J. Mamm. 63:176-179.

King, J., E. M. Sim., and S.A. Grant. 1984. Photosynthetic rate and carbon balance of grazed ryegrass pastures. Grass Forage Sci. 39:81-92.

Ludlow, M.M., and D.A. Charles-Edwards. 1980. Analysis of the regrowth of a tropical grass/legume sward subjected to different frequencies and intensities of defoliation. Aust. J. Agr. Res. 31:673-692.

MeNaughton, S.J., M.B. Coughenour, and L.L. Wallace. 1981. Interactive process in grassland ecosystems. p. 167-193. In: J.R. Estes, R.J. Tyrl and J.N. Brunken (eds.) Grasses and Grasslands. University of Oklahoma Press, Norman.

Nowak, R.S., and M.M. Caldwell. 1984. A test of compensatory photosynthesis in the field: implications for herbivory tolerance. Oecologia (Berlin) 61:311-318.

Painter, E.L., and J.K. Detling. 1981. Effects of defoliation on net photosynthesis and regrowth of western wheatgrass. J. Range Manage. 34:68-71.

Parsons, A.J., B. Collet, and J. Lewis. 1984. Changes in the structure and physiology of a perennial ryegrass sward when released from a continuous stocking management: implication for the use of exclusion cages in continuously stocked swards. Grass and Forage Sci. 39:1-9.

Reardon, P.O., C.L. Leinweber, and L.B. Merrill. 1974. Response of sideoats grama to animal saliva and thiamine. J. Range Manage. 27:400-401.
Robinson, R.R., W.H. Plerre, and R.A. Ackerman. 1937. A comparison of grazing and clipping for determining the response of permanent pastures to fertilization. Agron. J. 29:349-354.

Robineon, R.R., W.H. Plerre, and R.A. Ackerman. 1937. A comparison of grazing and clipping for determining the response of permanent pastures to fertilization. Agron. J. 29:349-354.

Sheehy, J.E., and D. Cook. 1977. Irradiance distribution and carbondioxide flux in forage grass canopies. Ann. Bot. 41:1017-1029.

Stroud, D.O., R.H. Hart, M.J. Samuel, and J.D. Rodgers. 1985. Western wheatgrass responses to simulated grazing. J. Range Manage. 38:103-108.

USDA 1976. Soil survey of Canadian County, Oklahoma. U.S. Gov. Print. Off., Washington, D.C.

Vickery, P.J. 1972. Grazing and net primary production of a temperate grassland. J. Appl. Ecol. 9:307-314.

Wallace, L.L., S.J.McNaughton, M.B. Coughenour. 1984. Compensatory photosynthetic responses of three African graminoids to different fertilization, watering and clipping regimes. Bot. Gaz. 145:151-156.

Wallace, L.L. 1987a. Mycorrhizas in grasslands: interactions of ungulates, fungi and drought. New Phytol. 105:619-632.

Wallace, L.L. 1987b. Effects of clipping and soil compaction on growth, morphology and mycorrhizal colonization of Schizachyrium scoparium, a C4 bunchgrass. Oecologia (Berlin) 72:423-428.

White, L.M. 1973. Carbohydrate reserves of grasses: a review. J. Range Manage. 26:13-18.

Wraith, J.M., D.A. Johnson, R.J. Hanks, and D.V. Sisson. 1987. Soil and plant water relations in a crested wheatgrass pasture: response to spring grazing by cattle. Oecologia (Berlin) 73:573-578. 